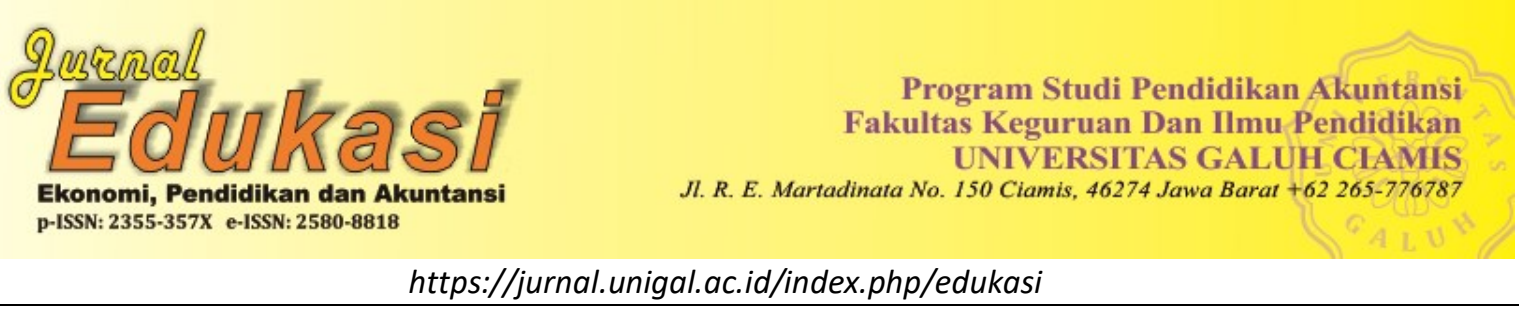

\title{
MENINGKATKAN HASIL BELAJAR DENGAN METODE TIME TOKEN
}

\author{
Oleh: \\ Rita Patonah ${ }^{1}$, Amelia Putri Suitela ${ }^{2}$ \\ Program Studi Pendidikan Akuntansi, FKIP Universitas Galuh \\ Email: ritadearly@gmail.com \\ Sejarah Artikel: Diterima Maret 2020, Disetujui April 2020, Dipublikasikan Juni 2020
}

\begin{abstract}
ABSTRAK
Rendahnya hasil belajar merupakan permasalahan dalam kegiatan pembelajaran. Salah satu alternatif pemecahannya yaitu penggunaan metode pembelajaran yang tepat. Salah satu metode pembelajaran yang dianggap relevan dengan mata pelajaran ekonomi yaitu metode time token. Penelitian ini bertujuan: 1) mengetahui peningkatan nilai pretest ke posttest peserta didik yang mendapatkan metode time token; 2) mengetahui perbedaan nilai posttest peserta didik yang menggunakan metode time token dengan metode ceramah. Metode penelitian menggunakan Quasi Experimental. Teknik analisis data yang digunakan adalah Uji Homogenitas (Uji F), Uji t dan Gain. Penelitian ini menghasilkan beberapa simpulan sebagai berikut : 1) Hasil belajar peserta didik yang menggunakan metode time token mengalami peningkatan 2) Terdapat perbedaan antara nilai posttest peserta didik yang menggunakan metode time token dengan yang menggunakan metode ceramah.
\end{abstract}

Kata kunci: metode time token, hasil belajar

\section{ABSTRACT}

Low learning results are a problem in learning activities. One effort to improve learning is the use of time token method. The purpose of this study is to find out: 1) the difference of posttest in student using the time token method 2)) the difference of posttest using the time token method in the experimental class with conventional.. The research method is used the Quasi experiation method. The data analysis techniques used are test homogenity (test F), Test $T$ and Gain. This study resulted in several sympulsion as follows: 1) There are different learners ' learning outcomes that use the time token method on the posttest. 2) There are different learners 'learning outcomes using the time token in the class of experiments with student learning outcomes using conventional methods at the final measurement (posttest).

Keyword: time token method, learning outcomes.

\section{PENDAHULUAN}

Keberhasilan atau kegagalan suatu proses pembelajaran bisa dilihat atau diukur melalui pencapaian hasil belajar. Menurut (Rusman, 2015:67) "hasil belajar adalah kemampuan yang dimiiki siswa setelah ia menerima pengalaman belajarnya". Guru sangat beperan dalam membantu ketercapaian hasil belajar. Sebelum pembelajaran dimulai guru diharuskan memilih metode pembelajaran yang relevan dengan materi dan karakteristik peserta didik agar pembelajaran dapat mencapai tujuan yang diharapkan.

Berdasarkan hasil observasi awal diketahui bahwa penggunaan metode dalam mengajar masih dominan konvensional sehingga menyebabkan belum optimalnya pencapaian hasil belajar sesuai dengan data berikut: 


\section{Tabel 1}

\section{Nilai Rata-Rata UAS Peserta Didik Pada Mata Pelajaran Ekonomi} Kelas X IPS SMA Negeri 1 Banjar

Tahun 2018/2019

\begin{tabular}{cccccccc}
\hline No & Kelas & $\begin{array}{c}\text { Jumlah } \\
\text { Peserta Didik }\end{array}$ & KKM & $\begin{array}{c}\text { Nilai di } \\
\text { Atas } \\
\text { KKM }\end{array}$ & Persentase & $\begin{array}{c}\text { Nilai di } \\
\text { Bawah } \\
\text { KKM }\end{array}$ & Persentase \\
\hline 1 & X IPS 1 & 36 & 75 & 3 & $8,33 \%$ & 33 & $91,67 \%$ \\
\hline 2 & X IPS 2 & 36 & 75 & 0 & $0 \%$ & 36 & $100 \%$ \\
\hline 3 & X IPS 3 & 36 & 75 & 2 & $5,56 \%$ & 34 & $94,44 \%$ \\
\hline 4 & X IPS 4 & 35 & 75 & 2 & $5,71 \%$ & 33 & $94,29 \%$ \\
\hline & Jumlah & 143 & 75 & 7 & & 136 & \\
\hline
\end{tabular}

Sumber : Guru Mata Pelajaran Ekonomi SMA Negeri 1 Banjar (2019)

Data pada tabel 1 menunjukan bahwa belum semua peserta didik mampu mencapai niai KKM bahkan prosentasenya sangat tinggi semuanya menunjukkan angka di atas $50 \%$ bahkan mencapai $90 \%$ lebih. Terdapat pula hal yang sangat ekstrim yaitu di kelas X IPS 2 seluruh siswa belum mampu mencapai nilai KKM. Hal tersebut menjadi permasalahan yang sangat serius yang harus diselesaikan oleh guru mata pelajaran ekonomi.

Penulis berasumsi bahwa dinilai perlu untuk menerapkan metode pembelajaran yang mampu meningkatkan hasil belajar. Salah satu metode pembelajaran yang diduga relevan untuk diterapkan dalam mata pelajaran ekonomi di SMA yaitu metode time token. Time token merupakan metode pembelajaran yang menuntut peserta didik untuk mencari materi dan menjawab pertanyaan dalam waktu yang cukup singkat. Time token merupkan metode yang akan menuntut peserta didik untuk berbicara atau menjawab, sehingga peserta didik akan aktif dalam pembelajaran. Hal tersebut sesuai dengan pendapat (Widodo dalam Shoimin, 2014:216) "metode pembelajaran time token sangat tepat untuk pembelajaran yang struktur yang dapat digunakan untuk mengajarkan keterampilan sosial, untuk menghindari siswa mendominasi pembicaraan atau siswa diam sama sekali”.

Melalui penerapan metode time token setiap peserta didik diharuskan berbicara atau memberikan suatu penjelasan tentang subjek yang sedang dibahas. Hal tersebut menuntut siswa untuk mampu mengemukakan argumen. Selain itu penerapan metode time token juga dapat menumbuhkan rasa percaya diri, menghargai pendapatan orang lain, mengemukakan ide-ide atau inisiatif dan partisipasinya dalam pembelajaran. Melalui penerapan metode time token diharapkan dapat meningkatkan antusiasme dan pada akhirnya berimplikasi pada perolehan hasil belajar yang meningkat.

\section{METODE PENELITIAN}

Penelitian menggunakan metode eksperimen dengan Quasi Eksperimental Design sebagaiman dijelaskan dalam tabel 2:

Tabel 2

Tabel Desain Penelitian

Quasi Experimental Design dengan tipe Nonequivalent Control Group Design

\begin{tabular}{cccc} 
Kelas & Tes Awal & Perlakuan & Tes Akhir \\
\hline Eksperimen & $\mathrm{O}_{1}$ & $\mathrm{X}$ & $\mathrm{O}_{2}$ \\
Kontrol & $\mathrm{O}_{3}$ & & $\mathrm{O}_{4}$
\end{tabular}

Keterangan :

$\mathrm{O}_{1}:$ Pretest kelas eksperimen

$\mathrm{O}_{2}:$ Posttest kelas eksperimen

$\mathrm{O}_{3}:$ Pretest kelas kontrol

$\mathrm{O}_{4}:$ Posttest kelas kontrol

$\mathrm{X}$ : Ttreatment metode time token 
Populasi dalam penelitian yaitu kelas X IPS SMA Negeri 1 Banjar Tahun Ajaran 2018/2019 yang berjumlah 143 orang. Teknik sampling menggunakan purposive sampling. Menurut (Sugiyono, 2015:124) "purposive sampling adalah teknik penentuan sampel dengan pertimbangan tertentu". Sampel yang digunakan yaitu X IPS 1 sebagai kelas kontrol dan X IPS 2 sebagai kelas eksperimen. Teknik pengumpulan data dilakukan dengan cara observasi, dokumentasi dan tes hasil belajar. Observasi dilakukan dengan cara mengamati proses pembelajaran dan mengamati perilaku belajar peserta didik. Dokumentasi dilakukan untuk memperolah data jumlah peserta didik dan nilai rata-rata ulangan ekonomi. Tes hasil belajar dilakukan berupa pemberian pretest dan posttest. Teknik analisis data dilakukan dengan menggunakan Uji t.

HASIL PENELITIAN DAN PEMBAHASAN

Berikut data hasil belajar yang menggunakan metode time token:

Tabel 3

Data Hasil Prestest dan Posttest Kelas Eksperimen

\begin{tabular}{cccccc} 
Kode Responden & Pretest & Posttest & Kode Responden & Pretest & Posttest \\
\hline 1 & 61,00 & 78,00 & 19 & 50,00 & 89,00 \\
2 & 50,00 & 72,00 & 20 & 50,00 & 83,00 \\
3 & 44,00 & 89,00 & 21 & 61,00 & 72,00 \\
4 & 67,00 & 67,00 & 22 & 50,00 & 89,00 \\
5 & 44,00 & 72,00 & 23 & 44,00 & 78,00 \\
6 & 44,00 & 78,00 & 24 & 72,00 & 89,00 \\
7 & 33,00 & 89,00 & 25 & 50,00 & 67,00 \\
8 & 44,00 & 78,00 & 26 & 56,00 & 78,00 \\
9 & 44,00 & 67,00 & 27 & 39,00 & 83,00 \\
10 & 56,00 & 83,00 & 28 & 56,00 & 78,00 \\
11 & 50,00 & 72,00 & 29 & 39,00 & 67,00 \\
12 & 44,00 & 67,00 & 30 & 44,00 & 83,00 \\
13 & 43,00 & 83,00 & 31 & 72,00 & 94,00 \\
14 & 78,00 & 89,00 & 32 & 50,00 & 83,00 \\
15 & 22,00 & 78,00 & 33 & 39,00 & 78,00 \\
16 & 39,00 & 78,00 & 34 & 50,00 & 67,00 \\
17 & 78,00 & 83,00 & 35 & 56,00 & 89,00 \\
18 & 50,00 & 89,00 & 36 & & 78,00 \\
\hline$X$ & & & & 1836,00 & 2857,00 \\
\hline & & & 51,00 & 79,36
\end{tabular}


Hasil Penelitian Tentang Perbedaan Hasil Belajar Yang Menggunakan Metode Time Token pada saat Pretest dan Posttest Kelas Eksperimen

Berikut langkah-langkah untuk melakukan Uji t :

a. Mempersiapan tabel perhitungan uji t, dengan format sebagai berikut :

Tabel 4

Tabel Perhitungan Uji t

\begin{tabular}{|c|c|c|c|c|c|c|}
\hline $\mathrm{N}$ & $\mathrm{X}_{1}$ & $\mathrm{X}_{2}$ & $\mathrm{X}^{\prime}{ }_{1}$ & $X^{\prime}{ }_{2}$ & $\mathrm{X}^{\prime}{ }^{2}$ & $\mathrm{X}^{\prime}{ }^{2}$ \\
\hline 1 & 78,00 & 61,00 & $-1,36$ & 10,00 & 1,85 & 100,00 \\
\hline 2 & 72,00 & 50,00 & $-7,36$ & $-1,00$ & 54,17 & 1,00 \\
\hline 3 & 89,00 & 44,00 & 9,64 & $-7,00$ & 92,93 & 49,00 \\
\hline 4 & 67,00 & 67,00 & $-12,36$ & 16,00 & 152,77 & 256,00 \\
\hline 5 & 72,00 & 44,00 & $-7,36$ & $-7,00$ & 54,17 & 49,00 \\
\hline 6 & 78,00 & 44,00 & $-1,36$ & $-7,00$ & 1,85 & 49,00 \\
\hline 7 & 89,00 & 33,00 & 9,64 & $-18,00$ & 92,93 & 324,00 \\
\hline 8 & 78,00 & 44,00 & $-1,36$ & $-7,00$ & 1,85 & 49,00 \\
\hline 9 & 67,00 & 44,00 & $-12,36$ & $-7,00$ & 152,77 & 49,00 \\
\hline 10 & 83,00 & 56,00 & 3,64 & 5,00 & 13,25 & 25,00 \\
\hline 11 & 72,00 & 50,00 & $-7,36$ & $-1,00$ & 54,17 & 1,00 \\
\hline 12 & 67,00 & 44,00 & $-12,36$ & $-7,00$ & 152,77 & 49,00 \\
\hline 13 & 83,00 & 43,00 & 3,64 & $-8,00$ & 13,25 & 64,00 \\
\hline 14 & 89,00 & 78,00 & 9,64 & 27,00 & 92,93 & 729,00 \\
\hline 15 & 78,00 & 22,00 & $-1,36$ & $-29,00$ & 1,85 & 841,00 \\
\hline 16 & 78,00 & 39,00 & $-1,36$ & $-12,00$ & 1,85 & 144,00 \\
\hline 17 & 83,00 & 78,00 & 3,64 & 27,00 & 13,25 & 729,00 \\
\hline 18 & 89,00 & 50,00 & 9,64 & $-1,00$ & 92,93 & 1,00 \\
\hline 19 & 89,00 & 50,00 & 9,64 & $-1,00$ & 92,93 & 1,00 \\
\hline 20 & 83,00 & 50,00 & 3,64 & $-1,00$ & 13,25 & 1,00 \\
\hline 21 & 72,00 & 61,00 & $-7,36$ & 10,00 & 54,17 & 100,00 \\
\hline 22 & 89,00 & 50,00 & 9,64 & $-1,00$ & 92,93 & 1,00 \\
\hline 23 & 78,00 & 44,00 & $-1,36$ & $-7,00$ & 1,85 & 49,00 \\
\hline 24 & 89,00 & 72,00 & 9,64 & 21,00 & 92,93 & 441,00 \\
\hline 25 & 67,00 & 50,00 & $-12,36$ & $-1,00$ & 152,77 & 1,00 \\
\hline 26 & 78,00 & 56,00 & $-1,36$ & 5,00 & 1,85 & 25,00 \\
\hline 27 & 83,00 & 39,00 & 3,64 & $-12,00$ & 13,25 & 144,00 \\
\hline 28 & 78,00 & 56,00 & $-1,36$ & 5,00 & 1,85 & 25,00 \\
\hline 29 & 67,00 & 39,00 & $-12,36$ & $-12,00$ & 152,77 & 144,00 \\
\hline 30 & 83,00 & 44,00 & 3,64 & $-7,00$ & 13,25 & 49,00 \\
\hline 31 & 94,00 & 72,00 & 14,64 & 21,00 & 214,33 & 441,00 \\
\hline 32 & 83,00 & 50,00 & 3,64 & $-1,00$ & 13,25 & 1,00 \\
\hline 33 & 78,00 & 39,00 & $-1,36$ & $-12,00$ & 1,85 & 144,00 \\
\hline 34 & 67,00 & 50,00 & $-12,36$ & $-1,00$ & 152,77 & 1,00 \\
\hline 35 & 89,00 & 56,00 & 9,64 & 5,00 & 92,93 & 25,00 \\
\hline 36 & 78,00 & 67,00 & $-1,36$ & 16,00 & 1,85 & 256,00 \\
\hline$\sum$ & 2857,00 & 1836,00 & 0,04 & 0,00 & 2202,31 & 5358,00 \\
\hline $\mathrm{X}$ & 79,36 & 51,00 & 0,00 & 0,00 & 61,18 & 148,83 \\
\hline
\end{tabular}

Keterangan :

$\begin{array}{ll}\mathrm{N} & \text { : jumlah sampel } \\ \mathrm{X}_{1} & \text { : nilai posttest } \text { kelas eksperimen } \\ \mathrm{X}_{2} & \text { : nilai } \text { pretest } \text { kelas eksperimen } \\ \bar{X}_{1} & : \mathrm{X}_{1}-\bar{X}_{1}\end{array}$ 


$$
\bar{X}_{2} \quad: \mathrm{X}_{2}-\bar{X}_{2}
$$

b. Menentukan mean atau nilai rata rata

$$
\bar{X}_{\text {圆 }}=\frac{\sum x_{i}}{n}
$$

1) Menentukan mean atau nilai rata-rata nilai pretest kelas eksperimen

$$
\begin{aligned}
& \bar{X}_{1}=\frac{\sum X_{1}}{n} \\
& \bar{X}_{1}=\frac{2857,00}{36} \\
& \bar{X}_{1} \quad=79,36
\end{aligned}
$$

2) Menentukan mean atau nilai rata-rata nilai posttest kelas eksperimen

$$
\begin{aligned}
& \bar{X}_{2}=\frac{\sum X_{2}}{n} \\
& \bar{X}_{2}=\frac{1836,00}{36} \\
& \bar{X}_{2}=51,00
\end{aligned}
$$

Berdasarkan hasil perhitungan di atas, maka diperoleh nilai $\bar{X}_{1} 79,36$ sebesar dan nilai $\bar{X}_{2}$ sebesar 51,00

c. Menentukan simpangan bahan baku atau standar deviasi

$$
S=\sqrt{\frac{\sum\left(x_{i}-\bar{X}\right)^{2}}{n-1}}
$$

1) Menentukan simpangan baku atau standar deviasi nilai posttestkelas eksperimen

$$
\begin{aligned}
& \mathrm{S}_{1}=\sqrt{\frac{\sum\left(x_{1}-\bar{X}\right)^{2}}{n-1}} \\
& \mathrm{~S}_{1}=\sqrt{\frac{2202,31}{36-1}} \\
& \mathrm{~S}_{1}=\sqrt{\frac{2202,31}{35}} \\
& \mathrm{~S}_{1}=\sqrt{62,92} \\
& \mathrm{~S}_{1}=7,93
\end{aligned}
$$

2) Menentukan simpangan baku atau standar deviasi nilai pretest kelas eksperimen

$$
\begin{aligned}
& \mathrm{S}_{2}=\sqrt{\frac{\sum\left(\mathrm{X}_{\mathrm{i}}-\bar{X}\right)^{2}}{n-1}} \\
& \mathrm{~S}_{2}=\sqrt{\frac{5358,00}{36-1}} \\
& \mathrm{~S}_{2}=\sqrt{\frac{5358,00}{35}} \\
& \mathrm{~S}_{2}=\sqrt{153,09} \\
& \mathrm{~S}_{2}=12,37
\end{aligned}
$$

Berdasarkan hasil perhitungan di atas, maka diperoleh nilai $S_{1}$ sebesar 7,93 dan $S_{2}$ sebesar 12,37

d. Menentukan nilai t hitung dengan rumus t- test

$$
t=\frac{\bar{X}_{1}-\bar{x}_{2}}{\sqrt{\frac{\left(S_{1}\right)^{2}}{n_{1}}+\frac{\left(S_{2}\right)^{2}}{n_{2}}}}
$$

Keterangan :

$\mathrm{t} \quad:$ thitung

$\mathrm{X}_{1}{ }_{1} \quad$ : Nilai rata - rata tes akhir (posttest) kelas eksperimen 
$\mathrm{X}_{2}{ }_{2} \quad$ : Nilai rata - rata tes awal (pretest) kelas eksperimen

$\mathrm{S}_{1} \quad$ : Standar devisiasi kelas eksperimen

$\mathrm{S}_{2} \quad$ : Standar devisiasi kelas eksperimen

$\mathrm{n}_{1} \quad$ : Banyaknya subyek kelompok kelas eksperimen

$\mathrm{n}_{2} \quad$ : Banyaknya subyek kelompok kelas eksperimen

$t=\frac{\bar{x}_{1}-\bar{x}_{2}}{\sqrt{\frac{\left(S_{1}\right)^{2}}{n_{1}}+\frac{\left(S_{2}\right)^{2}}{n_{2}}}}$

$t=\frac{79,36-51,00}{\sqrt{\frac{(7,93)^{2}}{36}+\frac{(12,37)^{2}}{36}}}$

$t=\frac{-28,36}{\sqrt{\frac{62,88}{36}+\frac{153,02}{36}}}$

$t=\frac{28,36}{\sqrt{1,75+4,25}}$

$t=\frac{28,36}{\sqrt{6}}$

$t=\frac{28,36}{2,45}$

$t=11,58$

e. Menentukan derajat kebebasan (dk) dengan menggunakan rumus sebagai berikut :

$\mathrm{dk}=\mathrm{n}_{1}+\mathrm{n}_{2}-2$

(Sugiyono, 2018:196)

Nilai t pada taraf kepercayaan $95 \%$ atau signifikansi 0,05 .

$\mathrm{dk}=\mathrm{n}_{1}+\mathrm{n}_{2}-2$

$\mathrm{dk}=36+36-2$

$\mathrm{dk}=70$

f. Menentukan besarnya $t_{\text {tabel }}$

Nilai $t_{\text {tabel }}$ pada derajat kebebasan $(\mathrm{dk})$ sebesar 70 dengan taraf kepercayaan 95\% (taraf nyata $\alpha=$ $0,05)$ adalah sebesar 1,67

g. Membandingkan nilai $t_{\text {hitung }}$ dengan $t_{\text {tabel }}$

Berdasarkan hasil perhitungan menggunakan rumus uji t-test diketahui $t_{\text {hitung }}$ sebesar 11,58 sedangkan $t_{\text {tabel }} 1,67$ maka nilai $t_{\text {hitung }}<t_{\text {tabel. }}$. Hal ini menujukan hasil belajar yang menggunakan metode time token berbeda pada saat pretest dan posttest.

Perbedaan tersebut dibuktikan dengan Gain sebagai berikut :

\section{Tabel 5}

Data Gain Kelas Eksperimen

\begin{tabular}{cccc} 
No & $\begin{array}{c}\text { Posttest Kelas } \\
\text { Eksperimen }\end{array}$ & $\begin{array}{c}\text { Pretest Kelas } \\
\text { Eksperimen }\end{array}$ & Gain \\
\hline 1 & 78,00 & 61,00 & 17,00 \\
2 & 72,00 & 50,00 & 22,00 \\
3 & 89,00 & 44,00 & 45,00 \\
4 & 67,00 & 67,00 & 0,00 \\
5 & 72,00 & 44,00 & 28,00 \\
6 & 78,00 & 44,00 & 34,00 \\
7 & 89,00 & 33,00 & 56,00
\end{tabular}




\begin{tabular}{cccc}
8 & 78,00 & 44,00 & 34,00 \\
9 & 67,00 & 44,00 & 23,00 \\
10 & 83,00 & 56,00 & 27,00 \\
11 & 72,00 & 50,00 & 22,00 \\
12 & 67,00 & 44,00 & 23,00 \\
13 & 83,00 & 43,00 & 40,00 \\
14 & 89,00 & 78,00 & 11,00 \\
15 & 78,00 & 22,00 & 56,00 \\
16 & 78,00 & 39,00 & 39,00 \\
17 & 83,00 & 78,00 & 5,00 \\
18 & 89,00 & 50,00 & 39,00 \\
19 & 89,00 & 50,00 & 39,00 \\
20 & 83,00 & 50,00 & 33,00 \\
21 & 72,00 & 61,00 & 11,00 \\
22 & 89,00 & 50,00 & 39,00 \\
23 & 78,00 & 44,00 & 34,00 \\
24 & 89,00 & 72,00 & 17,00 \\
25 & 67,00 & 50,00 & 17,00 \\
26 & 78,00 & 56,00 & 22,00 \\
27 & 83,00 & 39,00 & 44,00 \\
28 & 78,00 & 56,00 & 22,00 \\
29 & 67,00 & 39,00 & 28,00 \\
30 & 83,00 & 44,00 & 39,00 \\
31 & 94,00 & 72,00 & 22,00 \\
32 & 83,00 & 50,00 & 33,00 \\
33 & 78,00 & 39,00 & 39,00 \\
34 & 67,00 & 50,00 & 17,00 \\
35 & 89,00 & 56,00 & 33,00 \\
36 & 78,00 & 67,00 & 11,00 \\
\hline$\sum$ & & & 1021,00 \\
$X$ & & & 28,36 \\
& & &
\end{tabular}

Berdasarkan tabel 4 diketahui rata-rata peningkatan hasil belajar yang menggunakan metode time yaitu sebesar 28,36.

\section{Hasil Penelitian Tentang Perbedaan Hasil Belajar yang Mendapatkan Motode Time Token di Kelas Eksperimen dengan yang Mendapatkan Metode Ceramah di Kelas Kontrol}

Untuk mengukur perbedaan hasil belajar terebut dilakukan Uji t dengan langkah-langkah sebagai berikut :

a. Mempersiapan tabel perhitungan uji t dengan format sebagai berikut :

Tabel 6

Tabel Perhitungan Uji t

\begin{tabular}{ccccccc}
$\mathrm{N}$ & $\mathrm{X}_{1}$ & $\mathrm{X}_{2}$ & $\mathrm{X}^{\prime}{ }_{1}$ & $\mathrm{X}^{\prime}{ }{ }^{2}$ & $\mathrm{X}^{\prime}{ }^{2}{ }^{2}$ & $\mathrm{X}{ }^{2}{ }^{2}$ \\
\hline 1 & 78,00 & 67,00 & $-1,36$ & $-0,31$ & 1,85 & 0,10 \\
2 & 72,00 & 78,00 & $-7,36$ & 10,69 & 54,17 & 114,28 \\
3 & 89,00 & 72,00 & 9,64 & 4,69 & 92,93 & 22,00 \\
4 & 67,00 & 83,00 & $-12,36$ & 15,69 & 152,77 & 246,18 \\
5 & 72,00 & 83,00 & $-7,36$ & 15,69 & 54,17 & 246,18 \\
6 & 78,00 & 78,00 & $-1,36$ & 10,69 & 1,85 & 114,28 \\
7 & 89,00 & 78,00 & 9,64 & 10,69 & 92,93 & 114,28 \\
8 & 78,00 & 67,00 & $-1,36$ & $-0,31$ & 1,85 & 0,10 \\
9 & 67,00 & 50,00 & $-12,36$ & $-17,31$ & 152,77 & 299,64
\end{tabular}




\begin{tabular}{ccccccc}
10 & 83,00 & 61,00 & 3,64 & $-6,31$ & 13,25 & 39,82 \\
11 & 72,00 & 50,00 & $-7,36$ & $-17,31$ & 54,17 & 299,64 \\
12 & 67,00 & 56,00 & $-12,36$ & $-11,31$ & 152,77 & 127,92 \\
13 & 83,00 & 44,00 & 3,64 & $-23,31$ & 13,25 & 543,36 \\
14 & 89,00 & 83,00 & 9,64 & 15,69 & 92,93 & 246,18 \\
15 & 78,00 & 72,00 & $-1,36$ & 4,69 & 1,85 & 22,00 \\
16 & 78,00 & 61,00 & $-1,36$ & $-6,31$ & 1,85 & 39,82 \\
17 & 83,00 & 67,00 & 3,64 & $-0,31$ & 13,25 & 0,10 \\
18 & 89,00 & 56,00 & 9,64 & $-11,31$ & 92,93 & 127,92 \\
19 & 89,00 & 72,00 & 9,64 & 4,69 & 92,93 & 22,00 \\
20 & 83,00 & 78,00 & 3,64 & 10,69 & 13,25 & 114,28 \\
21 & 72,00 & 50,00 & $-7,36$ & $-17,31$ & 54,17 & 299,64 \\
22 & 89,00 & 44,00 & 9,64 & $-23,31$ & 92,93 & 543,36 \\
23 & 78,00 & 78,00 & $-1,36$ & 10,69 & 1,85 & 114,28 \\
24 & 89,00 & 89,00 & 9,64 & 21,69 & 92,93 & 470,46 \\
25 & 67,00 & 50,00 & $-12,36$ & $-17,31$ & 152,77 & 299,64 \\
26 & 78,00 & 67,00 & $-1,36$ & $-0,31$ & 1,85 & 0,10 \\
27 & 83,00 & 78,00 & 3,64 & 10,69 & 13,25 & 114,28 \\
28 & 78,00 & 50,00 & $-1,36$ & $-17,31$ & 1,85 & 299,64 \\
29 & 67,00 & 56,00 & $-12,36$ & $-11,31$ & 152,77 & 127,92 \\
30 & 83,00 & 94,00 & 3,64 & 26,69 & 13,25 & 712,36 \\
31 & 94,00 & 72,00 & 14,64 & 4,69 & 214,33 & 22,00 \\
32 & 83,00 & 83,00 & 3,64 & 15,69 & 13,25 & 246,18 \\
33 & 78,00 & 56,00 & $-1,36$ & $-11,31$ & 1,85 & 127,92 \\
34 & 67,00 & 72,00 & $-12,36$ & 4,69 & 152,77 & 22,00 \\
35 & 89,00 & 67,00 & 9,64 & $-0,31$ & 92,93 & 0,10 \\
36 & 78,00 & 61,00 & $-1,36$ & $-6,31$ & 1,85 & 39,82 \\
\hline$\Sigma$ & 2857,00 & 2423,00 & 0,04 & $-0,16$ & 2202,31 & 6179,64 \\
$\mathrm{X}$ & 79,36 & 67,31 & 0,00 & 0,00 & 61,18 & 171,66 \\
& & & & & &
\end{tabular}

Keterangan :

$\begin{array}{ll}\mathrm{N} & \text { : jumlah sampel } \\ \mathrm{X}_{1} & \text { : nilai posttest kelas eksperimen } \\ \mathrm{X}_{2} & \text { : nilai } \text { posttest kelas kontrol } \\ \mathrm{X}^{\prime}{ }_{1} & : \mathrm{X}_{1}-\bar{X}_{1} \\ \mathrm{X}^{\prime}{ }_{2} & : \mathrm{X}_{2}-\bar{X}_{2}\end{array}$

b. Menentukan mean atau nilai rata rata

$$
\bar{X}_{\text {圆 }}=\frac{\sum x_{i}}{n}
$$

1) Menentukan mean atau nilai rata-rata nilai posttest kelas eksperimen

$$
\begin{aligned}
& \bar{X}_{1}=\frac{\sum X_{1}}{n} \\
& \bar{X}_{1}=\frac{2857,00}{36} \\
& \bar{X}_{1} \quad=79,36
\end{aligned}
$$

2) Menentukan mean atau nilai rata-rata nilai posttest kelas kontrol

$$
\begin{aligned}
& \bar{X}_{2}=\frac{\sum X_{2}}{n} \\
& \bar{X}_{2}=\frac{2423_{3} 00}{36} \\
& \bar{X}_{2}=67,31
\end{aligned}
$$


Berdasarkan hasil perhitungan di atas, maka diperoleh nilai $\bar{X}_{1}$ sebesar 79,36 dan nilai $\bar{X}_{2}$ sebesar 67,31

c. Menentukan simpangan bahan baku atau standar deviasi

$S=\sqrt{\frac{\sum\left(x_{1}-\bar{X}\right)^{2}}{n-1}}$

(Sugiyono, 2013:57)

1) Menentukan simpangan baku atau standar deviasi nilai posttest kelas eksperimen

$$
\begin{aligned}
& \mathrm{S}_{1}=\sqrt{\frac{\sum\left(x_{\mathrm{i}}-\bar{X}\right)^{2}}{n-1}} \\
& \mathrm{~S}_{1}=\sqrt{\frac{2202,31}{36-1}} \\
& \mathrm{~S}_{1}=\sqrt{\frac{2202,31}{35}} \\
& \mathrm{~S}_{1}=\sqrt{62,92} \\
& \mathrm{~S}_{1}=7,93
\end{aligned}
$$

2) Menentukan simpangan baku atau standar deviasi nilai posttest kelas kontrol

$$
\begin{aligned}
& \mathrm{S}_{2}=\sqrt{\frac{\sum\left(x_{\mathrm{i}}-\bar{X}\right)^{2}}{n-1}} \\
& \mathrm{~S}_{2}=\sqrt{\frac{6179,64}{36-1}} \\
& \mathrm{~S}_{2}=\sqrt{\frac{6179,64}{35}} \\
& \mathrm{~S}_{2}=\sqrt{176,56} \\
& \mathrm{~S}_{2}=13,29
\end{aligned}
$$

Berdasarkan hasil perhitungan di atas, maka diperoleh nilai $\mathrm{S}_{1}$ sebesar 7,93 dan $\mathrm{S}_{2}$ sebesar 13,29

d. Menentukan nilai t hitung dengan rumus t- test

$$
t=\frac{\bar{x}_{1}-\bar{x}_{2}}{\sqrt{\frac{\left(S_{1}\right)^{2}}{n_{1}}-\frac{\left(S_{2}\right)^{2}}{n_{2}}}} \text { (Sugiyono 2015:273) }
$$

Keterangan :

$\mathrm{t} \quad: \mathrm{t}_{\text {hitung }}$

$\mathrm{X}^{\prime}{ }_{1}$ : Nilai rata - rata tes awal (pretest) kelas eksperimen

$\mathrm{X}^{\prime}{ }_{2}$ : Nilai rata - rata tes akhir (posttest) kelas kontrol

$\mathrm{S}_{1} \quad$ : Standar devisiasi kelas eksperimen

$\mathrm{S}_{2} \quad$ : Standar devisiasi kelas kontrol

$\mathrm{n}_{1} \quad$ : Banyaknya subyek kelompok kelas eksperimen

$\mathrm{n}_{2} \quad$ : Banyaknya subyek kelompok kelas kontrol

$$
\begin{aligned}
t & =\frac{\bar{x}_{1}-\bar{x}_{z}}{\sqrt{\frac{\left(S_{1}\right)^{2}}{n_{1}}+\frac{\left(S_{2}\right)^{2}}{n_{2}}}} \\
t & =\frac{79,36-67,31}{\sqrt{\frac{(2,98)^{2}}{\frac{8(18,29)^{2}}{86}}+\frac{196}{86}}} \\
t & =\frac{12,05}{\sqrt{\frac{62,89}{86}+176,62}} \\
t & =\frac{12,05}{\sqrt{1,75-4,91}} \\
t & =\frac{12,05}{\sqrt{6,66}}
\end{aligned}
$$




$$
\begin{aligned}
t & =\frac{12,05}{2,58} \\
t & =4,67
\end{aligned}
$$

e. Menentukan derajat kebebasan (dk) dengan menggunakan rumus sebagai berikut :

$$
\mathrm{dk}=\mathrm{n}_{1}+\mathrm{n}_{2}-2
$$

Nilai t pada taraf kepercayaan $95 \%$ atau signifikansi 0,05 .

$\mathrm{dk}=\mathrm{n}_{1}+\mathrm{n}_{2}-2$

$\mathrm{dk}=36+36-2$

$\mathrm{dk}=70$

f. Menentukan besarnya $t_{\text {tabel }}$

Nilai tabel pada derajat kebebasan (dk) sebesar 70 dengan taraf kepercayaan 95\% (taraf nyata $\alpha=$ $0,05)$ adalah sebesar 1,67

g. Membandingkan nilai $t_{\text {hitung }}$ dengan $t_{\text {tabel }}$

Berdasarkan hasil perhitungan menggunakan rumus uji t-test diketahui thitung 6,77 sedangkan nilai $t_{\text {abel }}$ sebesar 1,67 maka nilai $t_{\text {hitun }}>t_{\text {tabel. }}$. Hal ini menujukan bahwa hasil belajar peserta didik yang mendapatkan metode time token dikelas eksperimen berbeda dengan yang mendapatkan metode ceramah di kelas kontrol pada pengukuran akhir (posttest).

Perbedaan tersebut dibuktikan dengan perhitungan sebagai berikut :

Tabel 7

Data Gain Kelas Eksperimen dan Kelas Kontrol

\begin{tabular}{cccc} 
No & $\begin{array}{c}\text { Posttest Kelas } \\
\text { Eksperimen }\end{array}$ & $\begin{array}{c}\text { Posttest Kelas } \\
\text { Kontrol }\end{array}$ & Gain \\
\hline 1 & 78,00 & 67,00 & 11,00 \\
2 & 72,00 & 78,00 & $-6,00$ \\
3 & 89,00 & 72,00 & 17,00 \\
4 & 67,00 & 83,00 & $-16,00$ \\
5 & 72,00 & 83,00 & $-11,00$ \\
6 & 78,00 & 78,00 & 0,00 \\
7 & 89,00 & 78,00 & 11,00 \\
8 & 78,00 & 67,00 & 11,00 \\
9 & 67,00 & 50,00 & 17,00 \\
10 & 83,00 & 61,00 & 22,00 \\
11 & 72,00 & 50,00 & 22,00 \\
12 & 67,00 & 56,00 & 11,00 \\
13 & 83,00 & 44,00 & 39,00 \\
14 & 89,00 & 83,00 & 6,00 \\
15 & 78,00 & 72,00 & 6,00 \\
16 & 78,00 & 61,00 & 17,00 \\
17 & 83,00 & 67,00 & 16,00 \\
18 & 89,00 & 56,00 & 33,00 \\
19 & 89,00 & 72,00 & 17,00 \\
20 & 83,00 & 78,00 & 5,00 \\
21 & 72,00 & 50,00 & 22,00 \\
22 & 89,00 & 44,00 & 45,00 \\
23 & 78,00 & 78,00 & 0,00 \\
24 & 89,00 & 89,00 & 0,00 \\
25 & 67,00 & 50,00 & 17,00
\end{tabular}




\begin{tabular}{cccc}
26 & 78,00 & 67,00 & 11,00 \\
27 & 83,00 & 78,00 & 5,00 \\
28 & 78,00 & 50,00 & 28,00 \\
29 & 67,00 & 56,00 & 11,00 \\
30 & 83,00 & 94,00 & $-11,00$ \\
31 & 94,00 & 72,00 & 22,00 \\
32 & 83,00 & 83,00 & 0,00 \\
33 & 78,00 & 56,00 & 22,00 \\
34 & 67,00 & 72,00 & $-5,00$ \\
35 & 89,00 & 67,00 & 22,00 \\
36 & 78,00 & 61,00 & 17,00 \\
\hline$\sum$ & & & 434,00 \\
$X$ & & & 12,06
\end{tabular}

Berdasarkan tabel 6 diketahui perbedaan nilai rata-rata antara kelas eksperimen dengan kontrol sebesar 12,06.

\section{Pembahasan}

\section{Perbedaan Hasil Belajar di Kelas}

\section{Eksperimen yang Mendapatkan Metode}

Time Token

Hasil penelitian menunjukan bahwa hasil belajar peserta didik di kelas eksperimen yaitu kelas X IPS 2 yang mendapatkan metode time token mengalami peningkatan. Berdasarkan perhitungan diperoleh nilai rata-rata pretest sebesar 51,00 dan posttest sebesar 79,36. Peningkatan hasil belajar tersebut terjadi karena dalam metode time token peserta didik terlibat aktif dalam proses pembelajaran. peserta didik antusias dalam berpendapat, bertanya dan menganalisis asumsi yang mereka dapat. Peserta didik ikut terlibat dalam pembelajaran dan mendapatkan pengalaman langsung. Peserta didik membuat konsep materi dalam ingatannya sehingga melalui konsep tersebut materi pembelajaran dapat tertanam di memori mereka. Hal tersebut sejalan dengan pendapat (Huda, 2018:241) kelebihan pembelajaran time token antara lain :

1) Mendorong siswa untuk meningkatkan inisiatif dan partisipasi.

2) Menghindari dominasi siswa yang pandai berbicara atau yang tidak berbicara sama sekali.

3) Membantu siswa untuk aktif dalam kegiatan pembelajaran.

4) Meningkatkan kemampuan siswa dalam berkomunikasi (aspek berbicara).

5) Melatih siswa untuk mengungkapkan pendapat.

6) Menumbuhkan kebiasaan pada siswa untuk saling mendengar, berbagi, memberikan masukan, dan memiliki sikap keterbukaan terhadap kritik.

7) Mengajarkan siswa untuk menghargai pendapat orang lain.

8) Mengajarkan siswa mencari solusi bersama terhadap permasalahan yang dihadapi.

9) Tidak memerlukan banyak media pembelajaran.

Di dalam penerapan metode time token peserta didik mendapatkan peran atau terlibat pada pembelajaran secara langsung, karena setiap peserta didik diwajibkan untuk menggunakan kupon untuk mengutarakan argumennya di depan kelas sampai kupon tersebut habis. Metode pembelajaran time token menuntut siswa unuk terlibat aktif dalam diskusi sehingga menjadi lebih aktif dalam kegiatan pembelajaran. Hal tersebut sesuai dengan pendapat (Widodo dalam Shoimin, 2014:216) "metode pembelajaran time token sangat tepat untuk menghindari siswa mendominasi pembicaraan".

Perbedaan Hasil Belajar yang Mendapatkan Motode Time Token di Kelas Eksperimen dengan yang Mendapatkan Metode Konvensional di Kelas Kontrol

Hasil pengujian hipotesis menunjukan bahwa metode time token lebih unggul dan menghasilkan nilai akhir yang lebih besar dari metode pembelajaran konvensional pada kelas kontrol. Nilai rata-rata akhir kelas eksperimen sebesar 79,36 dan rata-rata nilai kelas kontrol sebesar 67,31 . 
Pada kelas eksperimen peserta didik tidak malu-malu untuk memberikan tanggapan, saran atau praktik berbicara didepan kelas. Masingmasing peserta didik telah diberikan kupon berbicara dan sebelumnya peserta didik harus menyerahkan kupon berbicara tersebut. Semua peserta didik menjadi tidak ragu untuk mengutarakan argumennya karena semua peserta didik memiliki kesempatan yang sama rata. Hal tersebut sesuai dengan pendapat Shoimin (2014:216) "model pembelajaran time token mengajak siswa aktif sehingga tepat digunakan dalam pembelajaran"

Hasil belajar yang mendapatkan metode ceramah kurang optimal. Hal tersebut dikarenakan metode konvensional lebih berpusat kepada guru yang mana peserta didik hanya menyimak dengan cara mendengarkan ceramah guru. Hal tersebut membuat peserta didik merasa bosan dalam menerima materi pembelajaran. Di dalam metode konvensional guru lebih berperan aktif dari pada peserta didik. Hal tersebut sesuai dengan pendapat Arifin (2013:197) kelemahan metode ceramah diantaranya:

1) Materi yang dapat dikuasai siswa sebagai hasil dari ceramah akan terbatas.

2) Ceramah yang tidak disertai dengan peragaan dapat mengakibatkan terjadinya verbalisme.

3) Ceramah sering dianggap sebagai metode yang membosankan.

4) Melalui ceramah sangat sulit untuk mengetahui apakah seluruh siswa sudah mengerti apa yang dijelaskan.

Di kelas kontrol tidak semua peserta didik ikut aktif saat proses pembelajaran berlangsung. Banyak peserta didik yang malumalu untuk memberikan tanggapan dan saran hanya peserta didik yang pandai yang aktif berbicara di depan kelas dan yang lainnya sangat pasif saat proses pembelajaran berlangsung. Suasana di dalam kelaspun menjadi sedikit lebih membosankan karena interaksi yang terjadi di dalam kelas tidak cukup baik. Hal tersebut berdampak pada kurang optimalnya ketercapaian tujuan pembelajaran. Metode konvensional akantepat dalam penerapannya apabila guru dapat memberikan variasi didalamnya agar kelas menjadi lebih hidup. Hal tersebut sesuai dengan pendapat (Jerome S. Bruner dalam Lestari dan Yudhanegara, 2017:33) "proses belajar akan berjalan dengan baik dan kreatif jika guru memberikan kesempatan kepada siswa untuk menemukan suatu konsep, teori, aturan atau pemahaman melalui contoh-contoh yang dijumpai dalam kehidupan".

Metode pembelajaran time token dan metode konvesional sama-sama memberikan kontribusi dalam meningkatkan hasil belajar. Namun metode time token dapat menghasilkan peningkatan lebih tinggi dibandingkan dengan metode konvensional.

\section{PENUTUP}

1. Hasil belajar yang menggunakan metode time token mengalami peningkatan yang siginifikan dari nilai pretest ke posttest yaitu dengan rata-rata 28,36 .

2. Peningkatan hasil belajar yang mendapatkan metode time token dikelas eksperimen lebih tinggi dibandingkan dengan yang mendapatkan metode konvensional di kelas kontrol pada pengukuran akhir (posttest).

\section{DAFTAR PUSTAKA}

Arifin, Zainal. 2013. Evaluasi Pembelajaran. Bandung.: PT. Remaja Rosdakarya.

Huda, Miftahul. 2018. Model-Model Pengajaran dan Pembelajaran.

Yogayakarta: Pustaka Belajar.

Lestari, K, E. Yudhanegara, M, R. 2017. Penelitian pendidikan Matematika. Bandung: PT Refika Aditama.

Rusman. 2015. Pembelajaran Tematik Terpadu Teori praktik dan Penilaian. Jakarta: PT Raja Grafindo Persada.

Shoimin, Aris. 2014. 68 Model Pembelajaran Inovatif dalam Kurikulum 2013. Yogyakarta: Ar-Ruzz Media

Sugiyono. 2013. Statistik untuk Penelitian. Bandung: Alfabeta.

Sugiyono. 2015. Metode Penelitian Pendidikan. Bandung: Alfabeta.

Sugiyono. 2018. Metode Penelitian Kuantitatif, Kualitatif dan $R \& D$. Bandung : Alfabeta 